\title{
Dietary Chicory Inulin-Rich Meal Exerts Greater Healing Effects than Fructooligosaccharide Preparation in Rats with Trinitrobenzenesulfonic Acid-Induced Necrotic Colitis
}

\author{
Bartosz Fotschki ${ }^{1}$, Adam Jurgoński ${ }^{1}$, Joanna Fotschki*, Michat Majewski ${ }^{3}$, Katarzyna Ognik ${ }^{4}$, Jerzy Juśkiewicz \\ ${ }^{1}$ Department of Biological Function of Food, Institute of Animal Reproduction and Food Research, \\ Division of Food Science, Olsztyn, Poland \\ ${ }^{2}$ Department of Immunology and Food Microbiology, Institute of Animal Reproduction and Food Research, \\ Division of Food Science, Olsztyn, Poland \\ ${ }^{3}$ Department of Pharmacology and Toxicology, Faculty of Medicine, University of Warmia and Mazury, Olsztyn, Poland \\ ${ }^{4}$ Department of Biochemistry and Toxicology, Faculty of Biology, \\ Animal Sciences and Bioeconomy, University of Life Sciences, Lublin, Poland
}

Key words: TNBS-induced colitis, microbiota activity, short-chain fatty acids, chicory roots, Wistar rat

The aim of this study was to compare the effects of chicory root inulin-rich meal (containing a polyphenolic fraction as well) and pure fructooligosaccharides (FOS) on necrotic colitis induced with trinitrobenzenesulfonic acid (TNBS) in Wistar rats. Both chicory preparations significantly reduced the $\mathrm{pH}$ value of colonic digesta and favourably lowered the caecal activity of bacterial $\beta$-glucuronidase as well as the caecal concentration of putrefactive short-chain fatty acids in comparison to the control TNBS rats. In addition, they enhanced the production of total short-chain fatty acid (SCFA pool) and concentration of anti-inflammatory propionic acid in the caecal digesta. Nevertheless, only dietary chicory meal favourably increased the total SCFA concentration and thus decreased the $\mathrm{pH}$ value of caecal digesta. The increased caecal SCFA production may explain the observed greater reduction in mucosal necrosis and increased glandular mucosal regeneration in rats fed a diet with chicory root meal. Both chicory preparations beneficially regulated physiological parameters in the lower part of the rat intestinal tract after TNBS-induced colitis, however the dietary treatment with chicory meal showed stronger reduction of mucosal disturbances caused by colitis. Those beneficial effects might be related to the higher polymerization of inulin $v s$. FOS and to the presence of biologically active compounds in the meal, i.e., phenolic compounds, which had a strong impact on intestinal microbial activity and thus indirectly alleviated mucosal disturbances caused by colitis.

\section{INTRODUCTION}

Inflammatory bowel disease (IBD) is a chronic disorder of the gastrointestinal tract whose etiology has not yet been fully elucidated [Motavallian-Naeini et al., 2012]. IBD is a multifactorial intestinal disorder that involves interactions among the immune system, genetic susceptibility and environmental factors, especially the intestinal microbiota [Witaicenis et al., 2010]. The incidence of IBD is continually increasing, and it has become a worldwide healthcare problem [Zhang \& Li, 2014]. There is evidence suggesting that the appropriate modulation of intestinal microbial activity regulates intestinal physiology and immunological function, which may assist in the prevention and treatment of IBD [Lara-Villoslada et al., 2006].

Well-known dietary ingredients that modulate the activity of the intestinal microbiota are nondigestible carbohydrates. Some studies have shown that a diet enriched in dietary fibre successfully maintains the remission of ulcerative colitis in hu-

\footnotetext{
* Corresponding Author: Tel.: +48 8952346 51;

E-mail: j.fotschki@pan.olsztyn.pl (J. Fotschki)
}

mans and experimental animal models because of an associated increase in the luminal production of short-chain fatty acids (SCFA) [Zhong et al., 2000; Rodríguez-Cabezas et al., 2002]. It has also been reported that dietary fructooligosaccharides (FOS) have a beneficial effect on intestinal inflammation in a rat model of colitis induced by trinitrobenzenesulfonic acid (TNBS); the applied dietary constituents reduced the extent of the damage and promoted epithelial healing [Cherbut et al., 2003]. These and other authors suggested that the main beneficial effects were associated with the end products of FOS fermentation, such as lactic acid and SCFA, as well as with the acidification of the luminal contents [Kosmala et al., 2015]. More complex nondigestible dietary carbohydrates that also modulate the activity of the microbiota in the gastrointestinal tract are inulin-type fructans [Juśkiewicz et al., 2011a]. Some studies have shown that dietary supplementation with these compounds beneficially stimulates the numbers of Biftdobacteria [Fotschki et al., 2014] and F. prausnitzii [Ramirez-Farias et al., 2009], as well as the production of SCFA [Fotschki et al., 2014; Kosmala et al., 2014].

Chicory is a rich source of dietary fibres such as inulin and FOS, which have health-promoting properties on consum- 
ers [Żary-Sikorska et al., 2016]. From all parts of the chicory plant (peel, seed, leaf), the highest content of inulin was determined in root [Jurgoński et al., 2011]. Inulin consists of linear chains of $\beta$-2,1-linked fructosyl units terminating at the reducing end with a glucose residue attached via a sucrose-type linkage. In nature, inulin is the second most abundant storage carbohydrate after starch [Singh et al., 2016]. Inulin is often used as a substrate to produce high purity FOS preparations [Ganaie et al., 2014]. Despite the differences in the degree of polymerization between inulin and FOS (inulin>FOS), both nondigestible carbohydrates have been termed 'prebiotics' [Gibson et al., 1995] and have been found to beneficially stimulate the growth and/or activity of the microbiota, thus affecting various physiological functions and ultimately having health-promoting impacts on consumers [Ganaie et al., 2014]. Nevertheless, the different degrees of polymerization of nondigestible carbohydrates have considerable effects on the specific activity of the microbiota and intestinal immune functions [Żary-Sikorska \& Juśkiewicz, 2008]. Moreover, unprocessed dietary fibre occurs as fibre-phenolic complexes, which present more health-promoting effects to consumers than the highly purified preparations of dietary fibre [Fotschki et al., 2015]. The chicory root is also a source of phenolic compounds, such as caffeoylquinic acids (CQAs) more specifically mono- and di-CQAs isomers [Jurgoński et al., 2011]. Zorrilla et al. [2014] showed that a polyphenolic-enriched almond extract can effectively improve epithelial barrier function and ameliorate colonic inflammation in a rat model of TNBS-induced colitis. Therefore, the present study with Wistar rats tested the hypothesis that dietary supplementation with unprocessed inulin-rich chicory root meal is more effective in reducing intestinal inflammation in a rat model of TBNS-induced colitis than are equivalents of highly purified chicory FOS.

\section{MATERIALS AND METHODS}

\section{Chicory preparations}

In this study, two kinds of chicory preparations were used: meal from chicory roots obtained from industrial processing and a commercial preparation of fructooligosaccharide produced via the enzymatic hydrolysis of chicory inulin (Raftilose ${ }^{\circledast}$ P95, ORAFTI, Belgium). The raw material used to produce the meal was industrially produced chicory semolina (ZPC Cykoria S.A., Poland) dried with a convective dryer at a temperature below $70^{\circ} \mathrm{C}$. The dried chicory material was disaggregated in a ball grinder and sieved through a screen with a mesh diameter of $0.8 \mathrm{~mm}$. The commercial dietary FOS preparation consisted of $96.4 \%$ dry matter, $0.83 \%$ ash, $0.6 \%$ glucose, and $95 \%$ short-chain FOS. The chicory root meal consisted of $96.7 \%$ dry matter, $5.87 \%$ crude protein, $1.81 \%$ crude fat, $3.32 \%$ ash, $6.25 \%$ cellulose, $4.30 \%$ monosaccharides, $75 \%$ fructans (15\% oligofructose and 60\% inulin), and $0.13 \%$ phenolic compounds. The determination of the proximate chemical composition was performed according to the method described in the previous studies [Jurgoński et al., 2011; Wang et al., 2018]. Total phenolic content was determined with the Folin-Ciocalteu's phenol reagent [De Pascual-Teresa et al., 2000]. Absorbance was mea- sured at $720 \mathrm{~nm}$ wavelength and chlorogenic acid was used as a standard (Sigma, Poznan, Poland).

\section{Animals and experimental design}

The rats were used in compliance with the European Guidelines for the Care and Use of Laboratory Animals [Directive 2010/63/EU], and the animal protocol was approved by the local institutional animal care and use committee (Permission No. 32/2012; Olsztyn, Poland). To determine the number of animals in group, the sample size estimation was done according to the approaches proposed by Dell et al. [2002]. The rats were housed individually. The selection of the animals and their maintenance over the experiment followed common regulations. The environment was controlled, with a 12-h light-dark cycle, a temperature of $21 \pm 1^{\circ} \mathrm{C}$, a relative humidity of $50 \pm 5 \%$, and 20 air changes $/ \mathrm{h}$. The experiment lasted 28 days and was conducted on 32 male Wistar rats aged 7 weeks and weighing $205.6 \pm 12.9 \mathrm{~g}$. The rats were divided into 4 groups. Each group was fed a modified version of the semipurified diet recommended for laboratory rodents. All experimental diets were similar in terms of dietary ingredients with the exception of the phenolic content and fibre source (Table 1). Healthy control rats and control rats with induced colitis were fed diets with dietary cellulose (groups $\mathrm{C}$ and $\mathrm{CC}$, respectively), and the rest of the rats with induced colitis were fed diets with either a dietary FOS preparation or chicory root meal (groups CCF and CCM, respectively). The rats had free access to tap water and the semipurified diets ad libitum, which were prepared and then stored at $4^{\circ} \mathrm{C}$ in hermetic containers until the end of the experiment.

\section{Assessment of colonic condition}

At the beginning of the experiment, all animals were fasted overnight and, except for the untreated control group, were rendered colitic by the method originally described by Morris

TABLE 1. Composition of experimental diets (\%).

\begin{tabular}{l|c|c|c}
\hline \multirow{2}{*}{} & \multicolumn{3}{|c}{ Group $^{1}$} \\
\cline { 2 - 4 } & C and CC & CCF & CCM \\
\hline Main components & 90 & 89.4 & 86.05 \\
\hline Fibre sources & 10.0 & - & - \\
Cellulose & - & 10.6 & - \\
FOS preparation & - & - & 13.5 \\
\multicolumn{1}{c}{ Chicory root meal } & 15.50 & 15.50 & 15.50 \\
\hline $\begin{array}{l}\text { Calculated content } \\
\text { Protein }\end{array}$ & 10.00 & 10.07 & 10.12 \\
$\begin{array}{l}\text { Fibre } \\
\text { Total phenolic } \\
\text { compounds }\end{array}$ & - & - & 0.018 \\
\hline
\end{tabular}

${ }^{1} \mathrm{C}$, healthy control rats fed dietary cellulose; $\mathrm{CC}$, control rats with induced colitis fed a diet with dietary cellulose; CCF; rats with induced colitis fed a diet with a dietary fructooligosaccharide preparation; CCM, rats with induced colitis fed a diet with chicory root meal; FOS, fructooligosaccharide preparation (Raftilose ${ }^{\circledR}$ P95, ORAFTI, Belgium). 
et al. [1989]. Briefly, the rats were anesthetised with isoflurane and given $10 \mathrm{mg}$ of TNBS (Sigma, Poznań, Poland) dissolved in $0.25 \mathrm{~mL}$ of $50 \%$ ethanol (v/v) by means of a Teflon cannula inserted $8 \mathrm{~cm}$ into the anus. The cannula was left in place for 1 min to ensure that the solution was not immediately expelled by the rat. Rats in the noncolitic group were intracolonically administered $0.25 \mathrm{~mL}$ of phosphate-buffered saline (PBS) instead of TNBS. The rats were kept in a head-down position for an additional $30 \mathrm{~s}$ and returned to their cages.

At the termination of the experiment, the rats were anaesthetized with sodium pentobarbital according to the recommendations for euthanasia of experimental animals. After laparotomy, the caecum and colon were removed and weighed. Subsequently, the colon was flushed with PBS and dried, and the tissue was immersed for 7 days in a $10 \%$ solution of buffered formalin. Colonic segments were embedded in paraffin blocks. Paraffin sections $(1-2 \mu \mathrm{m})$ were cut with a Reichert's microtome and tissue fragments were passed through increasing concentrations of alcohol solutions, acetone and xylene (de-waxed). The preparations were stained with hematoxylin and eosin (H\&E; Merck, Darmstadt, Germany) according to the method described by Fischer et al. [2008]. The tissue sections were evaluated and images taken by standard light microscopy using a computer program for image analysis, B-cell, and Olympus BX50 microscope with a digital camera (Olympus Co., Tokyo, Japan).

A semiquantitative score was used to evaluate severity of histological lesions in the inflamed colon (Histopathological Colitis Score, HCS) [Engel et al., 2008]. The HCS featured the parameters inflammation extent, crypt architecture, edema, and infiltration with inflammatory cells, with a maxi-

TABLE 2. Histopathological Colitis Score (HCS).

\begin{tabular}{lccc}
\hline Feature & Description & Score \\
\hline \multirow{2}{*}{ Inflammation extent } & none & 0 \\
& mucosa & 1 \\
& mucosa + submucosa & 2 \\
Damage in crypt & none & 0 \\
architecture & regeneration & 1 \\
& destruction & 2 \\
\hline \multirow{3}{*}{ Hyperemia / Edema } & without & 0 \\
& mild & 1 \\
& moderate & 2 \\
Infiltration with & severe & 3 \\
inflammatory cells & without & 0 \\
& mild & 2 \\
\hline
\end{tabular}

(ulceration and/or crypt abscess respectively +1 )

These features describe inflammation criteria to determine colitis severity [Engel et al., 2008]. mum of 12 points (Table 2). The cross-sectioned segments from the colon were scored by investigators, blinded to the experimental groups tested.

\section{Analytical procedures}

The individual feed consumption and final body weight of the rats were determined. Samples of the caecal and colonic digesta were collected, and their $\mathrm{pH}$ was immediately measured using a microelectrode and a $\mathrm{pH} / \mathrm{ION}$ meter (model 301; Hanna Instruments, Vila do Conde, Portugal). In the fresh caecal digesta, the dry matter was determined by drying to constant weight at $105^{\circ} \mathrm{C}$, whereas the ammonia concentration was determined by the microdiffusion method in Conway's dishes [Hofirek \& Haas, 2001].

After storage of the caecal digesta at $-70^{\circ} \mathrm{C}$, SCFA concentrations were measured using a gas chromatography system (Shimadzu GC-2010, Kyoto, Japan) with a capillary column (SGE BP21, $30 \mathrm{~m} \times 0.53$ mm; SGE Europe Ltd., Milton Keynes, UK), as previously described [Jurgoński et al., 2015]. The concentrations of the caecal putrefactive SCFA (PSCFA) were calculated as the sum of isobutyric, isovaleric, and valeric acids. All SCFAs analyses were performed in duplicate. Standards of acetic, propionic, butyric, isobutyric, isovaleric, and valeric acids were obtained from Sigma Co. (Poznań, Poland). They were used to plot calibration curves and calculate individual fatty acid concentration in the digesta.

Caecal fermentation processes were analysed based on the activities of selected bacterial enzymes ( $\alpha$-and $\beta$-glucosidase, $\alpha$ - and $\beta$-galactosidase, and $\beta$-glucuronidase), as measured by the rate of release of $p$-nitrophenol or $o$-nitrophenol from the respective nitrophenyl glucosides, according to a previously described method [Juśkiewicz et al., 2011b]. The following substrates were used: $p$-nitrophenyl- $\alpha$-D-glucopyranoside (for $\alpha$-glucosidase), $p$-nitrophenyl- $\beta$-D-glucopyranoside (for $\beta$-glucosidase), $p$-nitrophenyl- $\alpha$-D-galactopyranoside (for $\alpha$-galactosidase), $\alpha$-nitrophenyl- $\beta$-D-galactopyranoside (for $\beta$-galactosidase), and $p$-nitrophenyl- $\beta$-D-glucuronide (for $\beta$-glucuronidase). To measure the activities of enzymes secreted by bacterial cells into the caecal environment, a reaction mixture containing $0.3 \mathrm{~mL}$ of a substrate solution $(5 \mathrm{mM})$ and $0.2 \mathrm{~mL}$ of a 1:10 (v/v) dilution of the caecal sample in $100 \mathrm{mM}$ phosphate buffer $(\mathrm{pH}$ 7.0) after centrifugation at $4^{\circ} \mathrm{C}, 7211 \times \mathrm{g}(\mathrm{MPW}-350 \mathrm{R}, \mathrm{MPW}$ Med. Instruments, Warsaw, Poland) for $15 \mathrm{~min}$ was prepared. The samples were incubated $\left(10-\mathrm{min}, 37^{\circ} \mathrm{C}\right.$ ) and then mixed with $2.5 \mathrm{~mL}$ of $0.25 \mathrm{M}$ cold sodium carbonate to stop the reaction. The absorbance was measured at $400 \mathrm{~nm}$ for $p$-nitrophenol and at $420 \mathrm{~nm}$ for $o$ nitrophenol (Spectrophotometer Unicam Helios $\alpha$, Thermo Fisher Scientific Polska Sp. z o.o., Warsaw, Poland). The enzymatic activity was expressed as $\mu$ mol product formed per hour per $g$ of fresh digesta. All analyses were performed in duplicate.

\section{Statistical analysis}

The results were examined statistically using one-way analysis of variance, and significant differences between groups were determined with Duncan's multiple range test at a significance level of $\mathrm{P} \leq 0.05$. Calculations were made using STATISTICA 12.0 software (StatSoft Corp., Kraków, Poland). 
TABLE 3. Body weight, diet intake, and basic indices of the distal intestine in rats with TNBS-induced colitis.

\begin{tabular}{|c|c|c|c|c|}
\hline & \multicolumn{4}{|c|}{ Group $^{1}$} \\
\hline & $\mathrm{C}$ & $\mathrm{CC}$ & $\mathrm{CCF}$ & $\mathrm{CCM}$ \\
\hline Initial body weight (g) & $206 \pm 4$ & $205 \pm 3$ & $205 \pm 4$ & $206 \pm 3$ \\
\hline Final body weight (g) & $309 \pm 7^{a}$ & $264 \pm 4^{b}$ & $279 \pm 4^{b}$ & $279 \pm 8^{\mathrm{b}}$ \\
\hline Diet intake (g/4 weeks) & $557 \pm 15^{\mathrm{a}}$ & $477 \pm 13^{\text {bc }}$ & $456 \pm 13^{c}$ & $500 \pm 9^{\mathrm{b}}$ \\
\hline Feed conversion ratio $(\mathrm{g} / \mathrm{g}$ ) & $5.50 \pm 0.26^{\mathrm{b}}$ & $8.61 \pm 0.79^{\mathrm{a}}$ & $6.53 \pm 0.57^{b}$ & $7.35 \pm 0.82^{\mathrm{ab}}$ \\
\hline \multicolumn{5}{|c|}{ Caecum } \\
\hline Tissue mass ${ }^{2}$ & $0.27 \pm 0.01^{\mathrm{c}}$ & $0.32 \pm 0.02^{\mathrm{c}}$ & $0.61 \pm 0.02^{\mathrm{a}}$ & $0.43 \pm 0.02^{\mathrm{b}}$ \\
\hline Digesta mass ${ }^{2}$ & $0.83 \pm 0.04^{c}$ & $0.92 \pm 0.04^{\mathrm{bc}}$ & $1.83 \pm 0.18^{\mathrm{a}}$ & $1.21 \pm 0.14^{\mathrm{b}}$ \\
\hline $\mathrm{pH}$ of digesta & $6.82 \pm 0.06^{\mathrm{a}}$ & $6.81 \pm 0.06^{\mathrm{a}}$ & $6.33 \pm 0.15^{\mathrm{ab}}$ & $6.21 \pm 0.14^{\mathrm{b}}$ \\
\hline Dry matter of digesta $(\%)$ & $23.9 \pm 0.53^{\mathrm{a}}$ & $24.3 \pm 0.53^{\mathrm{a}}$ & $18.4 \pm 0.93^{b}$ & $16.4 \pm 0.40^{c}$ \\
\hline Ammonia in digesta $(\mathrm{mg} / \mathrm{g})$ & $0.36 \pm 0.02$ & $0.38 \pm 0.02$ & $0.38 \pm 0.03$ & $0.34 \pm 0.02$ \\
\hline \multicolumn{5}{|c|}{ Colon } \\
\hline Mass with digesta ${ }^{2}$ & $0.99 \pm 0.04^{b}$ & $3.54 \pm 0.49^{\mathrm{a}}$ & $1.09 \pm 0.10^{\mathrm{b}}$ & $1.01 \pm 0.10^{\mathrm{b}}$ \\
\hline $\mathrm{pH}$ of digesta & $6.80 \pm 0.13^{\mathrm{ab}}$ & $7.06 \pm 0.06^{\mathrm{a}}$ & $6.59 \pm 0.15^{b}$ & $6.44 \pm 0.06^{\mathrm{b}}$ \\
\hline
\end{tabular}

Values are expressed as the mean \pm standard error of the mean; TNBS, trinitrobenzenesulfonic acid. ${ }^{1} \mathrm{C}$, healthy control rats fed a diet with dietary cellulose; CC, control rats with induced colitis fed a diet with dietary cellulose; CCF, rats with induced colitis fed a diet with a dietary fructooligosaccharide preparation; CCM, rats with induced colitis fed a diet containing chicory root meal. ${ }^{2} \mathrm{~g} / 100 \mathrm{~g}$ body weight. ${ }^{\mathrm{a}-\mathrm{C}}$ Values with different superscript letters within a row are significantly different at $\mathrm{P} \leq 0.05$.

\section{RESULTS AND DISCUSSION}

In the present study, after 28 days of the experiment, the animals administered TNBS exhibited the overt typical clinical signs of colitis: lesser weight gain related to a decrease of diet intake and an increase in the feed conversion ratio (C vs. CC; $\mathrm{P}<0.05$ ) (Table 3). Similar signs were observed by Gonçalves et al. [2013] in Wistar rats with TNBS-induced colitis. Compared to the untreated animals (C group), the induction of colitis in the $\mathrm{CC}$ group was manifested by a significant increase of the colon mass with digesta (Table 3 ) and activity of caecal bacterial $\beta$-glucosidase $(\mathrm{P}<0.05$; Table 3$)$. The results obtained in the present study showed that diet enrichment with chicory preparations, especially chicory root meal, partly reduced these typical clinical signs of the TNBS-induced inflammatory process.

The experimental groups of animals with TNBS-induced colitis (CCF and CCM) consumed less food and thus gained significantly less in weight than the rats from group $\mathrm{C}$ (Table 3). Among the rats treated with TNBS, the dietary intake differed between the $\mathrm{CCF}$ and $\mathrm{CCM}$ groups $(\mathrm{CCF}<\mathrm{CCM}$; $\mathrm{P}<0.05)$. Animals fed the diet with FOS utilised the diet significantly better than the control group animals with induced colitis ( $\mathrm{CC}$ group; $\mathrm{P}<0.05)$. The highest relative caecal tissue mass was noted in the rats fed dietary FOS, and the values of that parameter decreased as follows among the groups: $\mathrm{CCF}>\mathrm{CCM}>\mathrm{CC}$. Dietary inclusion of the FOS preparation resulted in a significant increase in the caecal digesta mass in comparison to other groups $(\mathrm{P}<0.05)$. The concentrations of caecal digesta dry matter in the CCF and CCM groups vs. those of the $\mathrm{C}$ and $\mathrm{CC}(\mathrm{P}<0.05)$ groups, were respectively reduced.

The administration of experimental diets to the rats with TNBS-induced colitis caused positive effect by decreasing $\beta$-glucuronidase activity in the caecal digesta $(\mathrm{CCF}$, $\mathrm{CCM}$ vs. $\mathrm{CC} ; \mathrm{P}<0.05)$ and compensating the increase of the $\beta$-glucosidase during the inflammation processes caused by TNBS (Table 4). Bacterial enzymes, such as $\beta$-glucuronidase, may exert toxic, carcinogenic or mutagenic effects in the colon [Klewicka et al., 2009]. Roberton et al. [1982] suggested that the most important factor in the modulation of $\beta$-glucuronidase activity in the rat large bowel is bile flow. Dietary fibre increases peristalsis, and thus greater quantities of bile are transported to distal segments of the gastrointestinal tract. Some studies reported that diet with dietary fibres and polyphenols may reduce the activity of such enzymes as $\beta$-glucuronidase and $\beta$-glucosidase [Lahouar et al., 2012; Kosmala et al., 2017]. Juśkiewicz et al. [2011b] also examined the effects of the chicory dietary polyphenolic fraction and found favourable changes in the activity of bacterial $\beta$-glucuronidase in the faeces and caecal digesta of rats.

In comparison to the dietary treatment with cellulose, dietary inclusion of the commercial FOS preparation as well as chicory root meal exerted a positive effect by lowering the $\mathrm{pH}$ value in the colonic digesta (Table 3). It is noteworthy that the acidification of the digesta promotes positive microbiota proliferation and decreases the growth of pathogenic bacterial species [Topping \& Clifton, 2001]. In the CCM group, this dietary preparation lowered the percentage of dry matter and the $\mathrm{pH}$ value in the caecum (Table 3), indicating more intensive fermentation of indigestible components ahead 
TABLE 4. Microbial enzyme activities and short-chain fatty acid (SCFA) concentrations, profile, and pool in the caecal digesta.

\begin{tabular}{|c|c|c|c|c|}
\hline & \multicolumn{4}{|c|}{ Group $^{1}$} \\
\hline & $\mathrm{C}$ & $\mathrm{CC}$ & $\mathrm{CCF}$ & $\mathrm{CCM}$ \\
\hline \multicolumn{5}{|c|}{ Enzyme activity ( $\mu \mathrm{mol} / \mathrm{h} / \mathrm{g}$ digesta) } \\
\hline$\alpha$-Glucosidase & $10.9 \pm 1.16^{\mathrm{b}}$ & $11.6 \pm 3.11^{\mathrm{b}}$ & $47.0 \pm 6.16^{\mathrm{a}}$ & $30.2 \pm 5.59^{\mathrm{a}}$ \\
\hline$\beta$-Glucosidase & $5.29 \pm 0.82^{\mathrm{c}}$ & $13.1 \pm 1.8^{\mathrm{a}}$ & $7.57 \pm 0.80^{\mathrm{bc}}$ & $9.48 \pm 1.21^{\mathrm{ab}}$ \\
\hline$\alpha$-Galactosidase & $6.28 \pm 1.17^{\mathrm{c}}$ & $10.9 \pm 1.80^{\mathrm{bc}}$ & $55.6 \pm 8.50^{\mathrm{a}}$ & $31.0 \pm 5.73^{\mathrm{ab}}$ \\
\hline$\beta$-Galactosidase & $24.0 \pm 1.80^{\mathrm{c}}$ & $27.6 \pm 1.85^{\mathrm{bc}}$ & $222 \pm 21.45^{\mathrm{a}}$ & $128 \pm 11.33^{\mathrm{ab}}$ \\
\hline$\beta$-Glucuronidase & $18.8 \pm 2.8^{\mathrm{ab}}$ & $30.4 \pm 4.7^{\mathrm{a}}$ & $8.69 \pm 1.46^{\mathrm{b}}$ & $8.63 \pm 2.43^{b}$ \\
\hline $\begin{array}{l}\text { SCFA concentration } \\
\text { (mmol/g digesta) }\end{array}$ & $91.8 \pm 7.1^{\mathrm{b}}$ & $88.9 \pm 6.6^{\mathrm{b}}$ & $98.3 \pm 9.9^{b}$ & $141 \pm 9^{a}$ \\
\hline Acetic acid & $66.4 \pm 5.94$ & $63.0 \pm 5.1$ & $53.1 \pm 5.7$ & $71.5 \pm 5.1$ \\
\hline Propionic acid & $14.4 \pm 1.23^{\mathrm{b}}$ & $14.9 \pm 1.2^{\mathrm{b}}$ & $38.0 \pm 6.1^{\mathrm{a}}$ & $61.3 \pm 8.0^{\mathrm{a}}$ \\
\hline Butyric acid & $8.89 \pm 0.74^{\mathrm{a}}$ & $8.14 \pm 0.70^{\mathrm{a}}$ & $5.59 \pm 0.42^{\mathrm{b}}$ & $6.86 \pm 0.81^{\mathrm{ab}}$ \\
\hline $\mathrm{PSCFA}^{2}$ & $2.16 \pm 0.20^{\mathrm{ab}}$ & $2.79 \pm 0.29^{\mathrm{a}}$ & $1.60 \pm 0.54^{\mathrm{b}}$ & $1.16 \pm 0.29^{\mathrm{b}}$ \\
\hline \multicolumn{5}{|l|}{ SCFA profile $(\%)$} \\
\hline Acetic acid & $72 \pm 1.3^{\mathrm{a}}$ & $71 \pm 1.2^{\mathrm{a}}$ & $55 \pm 1.3^{\mathrm{b}}$ & $51 \pm 3.4^{\mathrm{b}}$ \\
\hline Propionic acid & $16 \pm 0.6^{\mathrm{b}}$ & $17 \pm 0.5^{\mathrm{b}}$ & $37 \pm 2.1^{\mathrm{a}}$ & $43 \pm 3.5^{\mathrm{a}}$ \\
\hline Butyric acid & $10 \pm 1.2^{\mathrm{a}}$ & $9 \pm 0.8^{\mathrm{a}}$ & $6 \pm 0.9^{b}$ & $5 \pm 0.7^{\mathrm{b}}$ \\
\hline $\begin{array}{l}\text { SCFA pool }(\mathrm{mmol} / 100 \mathrm{~g} \\
\text { body weight) }\end{array}$ & $77.1 \pm 8.4^{b}$ & $86.4 \pm 5.5^{\mathrm{b}}$ & $169 \pm 11^{\mathrm{a}}$ & $173 \pm 24^{a}$ \\
\hline
\end{tabular}

Values are expressed as the mean \pm standard error of the mean. The colitis has been induced by trinitrobenzenesulfonic acid (TNBS). ${ }^{1} \mathrm{C}$, healthy control rats fed a diet with dietary cellulose; CC, control rats with induced colitis fed a diet with dietary cellulose; CCF, rats with induced colitis fed a diet with a dietary fructooligosaccharide preparation; CCM, rats with induced colitis fed a diet containing chicory root meal. ${ }^{2}$ Short-chain fatty acids of putrefactive origin (isobutyric acid + isovaleric acid + valeric acid). ${ }^{\text {acc } V a l u e s ~ w i t h ~ d i f f e r e n t ~ s u p e r s c r i p t ~ l e t t e r s ~ w i t h i n ~ a ~ r o w ~ a r e ~ s i g n i f i c a n t l y ~ d i f f e r e n t ~}$ at $\mathrm{P} \leq 0.05$.

of the colon. In the examined preparations, only the feeding with the diet with chicory root meal was able to significantly elevate the caecal concentration of SCFAs, as the main fermentation products of the abundant microbiota (Table 4). The caecal SCFAs pool was found to be significantly increased upon dietary application of both tested preparations (CCF and $\mathrm{CCM}$ vs. $\mathrm{C}$ and $\mathrm{CC} ; \mathrm{P}<0.05)$. The SCFAs are essential for the constant repair of the colon epithelium [Sturm \& Dignass, 2008] and exert anti-inflammatory and anticarcinogenic effects [Van der Beek et al., 2017]. The secretory response to SCFAs, in combination with the contractile response, seems to act as a lubricant for the movement of luminal content in the colon [Yajima et al., 2011]. In addition, dietary application of chicory preparations resulted in the highest caecal propionic acid concentration (CCF and CCM vs. C and CC, respectively; $\mathrm{P}<0.05)$. As a result, in comparison to control animals the application of both experimental diets (CCF, CCM) significantly increased percentage of propionic acid in the SCFA profile at the expense of acetic and butyric acids $(\mathrm{P}<0.05)$ (Table 4). Acetic and propionic acids are known to reduce the production of anti-inflammatory mediators such as TNF- $a$ by human neutrophils. Propionic acid is also able to inhibit the expression of proinflammatory mediators [Vinolo et al., 2011]; in addition it stimulates chloride secretion and exerts a range of health-promoting functions
[Yajima et al., 2011; Louis \& Flint, 2017]. Jurgoński et al. [2011] found no significant difference in the production of butyric acid in the caecum of rats fed a diet supplemented with chicory root extract. In the present study, the caecal concentration of butyric acid, which is a major nutritive factor for colonic enterocytes, was reduced when the rats were feed CCF and CCM diets. The butyric acid exhibits a wide spectrum of cellular effects on the mucosa, such as enhanced differentiation and apoptosis. It is presumed that butyric acid exerts local anti-inflammatory effects [Hamer et al., 2008]. In the studies performed on the isolated perfused rat colon, it has been shown that butyric acid increased the secretion of mucin [Barcelo et al., 2000; Shimotoyodome et al., 2000]. Putrefactive SCFAs are products of bacterial fermentation of undigested proteins [Cardona et al., 2005]. Both experimental groups, in comparison to the CC group, exhibited significantly reduced production of PSCFAs (Table 4), which may suggest the less intensive anaerobic bacterial fermentation of polypeptides and amino acids.

The histological examination of the colonic tissue in rats not treated with TBNS showed normal morphology of the mucosa. Numerous small lumps of lymphocytes were found in the mucosa (Figure 1). The number of lumps appearing in the lymph mucosa was higher, and they had the characteristics of proliferated lymphocytes with few eo- 

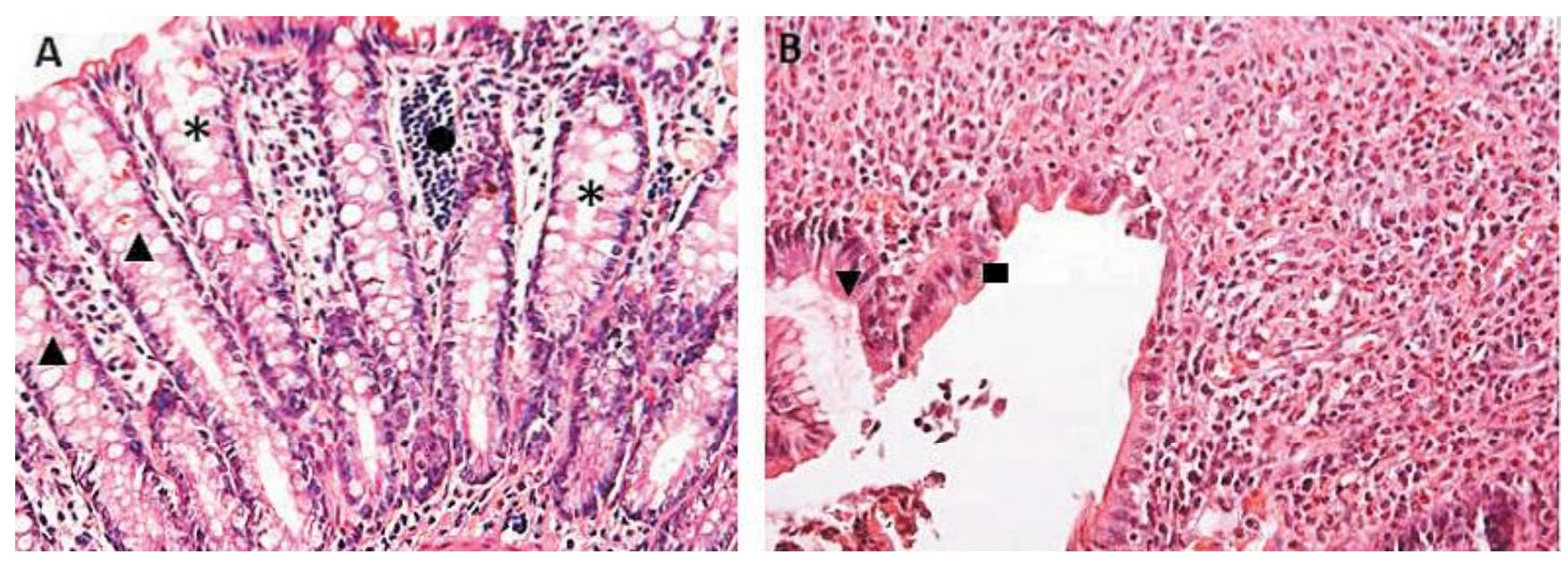

FIGURE 1. A - Example of colonic mucosa from the healthy control (C group) Wistar rat group; Goblet cells (black triangles); Intestinal glands in the crypts (black asterisks); Small clump of lymphocytes (black dot); B - Regeneration of mucosal glands in a rat from the colitic control group (CC group); Brush border (black square); Simple columnar epithelium (black arrowhead). The specimens were stained with hematoxylin and eosin. The original magnification was $40 \times$
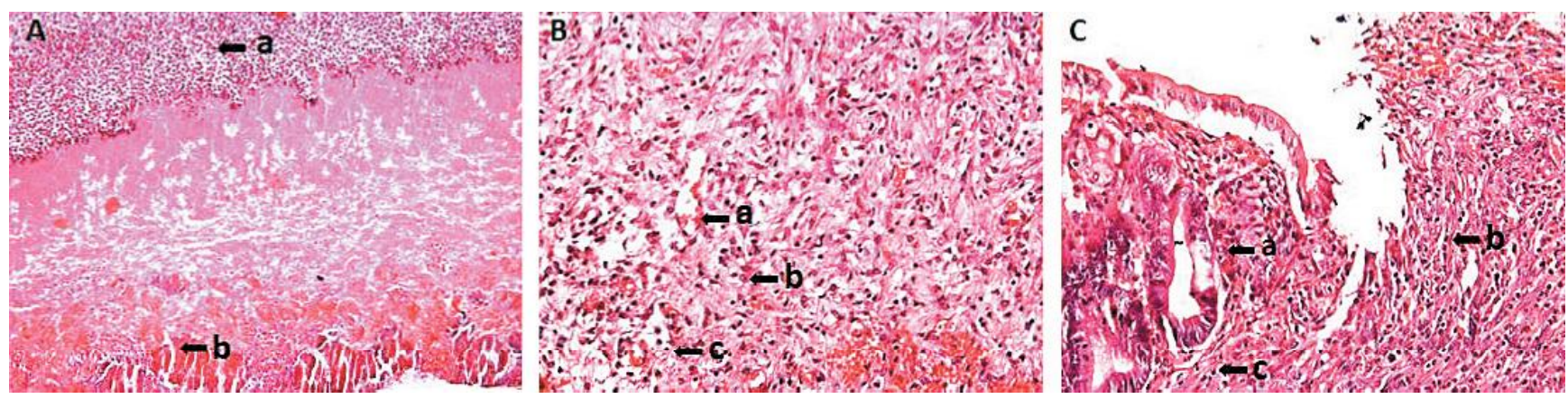

FIGURE 2. A - Necrosis of colonic mucosa and leukocyte infiltration in a rat from the colitic group fed a dietary fructo-oligosaccharide preparation (CCF group); a -leukocytes; $\mathrm{b}$ - necrotic changes; B - Thick layer of young connective tissue (granulation) with fibroblasts under the dead mucosa in a rat from the colitic group fed chicory root meal; a - erythrocytes, b - macrophages; c - lymphocytes (CCM group); C - Mucosal regeneration on the border of damage in a rat from the colitic group fed a diet containing chicory root meal (CCM group). Glandular cells are seen arising on young granulation tissue, in which eosinophils are present alongside fibroblasts; $\mathrm{a}$ - macrophages; $\mathrm{b}$ - eosinophils, $\mathrm{c}$ - lymphocytes. The specimens were stained with hematoxylin and eosin. The original magnification was $20 \times(\mathrm{A})$ and $40 \times(\mathrm{B}, \mathrm{C})$.

sinophil cells. The administration of TNBS, which induces inflammation in rats, significantly increased the weight of the colon. This observed effect might be related to a higher level of edema and inflammatory processes. The administration of TNBS resulted in widespread mucosal necrotic inflammation in the entire colon in all animals. A similar effect was observed by Yue-Meng et al. [2011] in a nutritional study regarding the therapeutic effects of Peifeikang (a probiotic compound) on rats with experimental TNBS-induced colitis. The defensive response to the necrotic inflammation observed in all animals was leukocyte (neutrophil) infiltration. Neutrophil infiltration is one of the most prominent histological features in the inflamed colonic mucosa of colitis [Liu \& Wang, 2011]. In the present study, the largest regenerative changes in the colon were found in the group fed chicory root meal. The lowest average thickness of tissue necrosis was observed in the animals from the CCM group, and this thickness increased among the groups as follows: $\mathrm{CCM}<\mathrm{CCF}<\mathrm{CC}$ $(\mathrm{P}<0.05)$ (Table 5). The observed beneficial effects might be related to the production of SCFA and to the regulation of leukocytes ability to migrate to loci of inflammation
[Vinolo et al., 2011]. The SCFAs regulate differentiation of mucosal $\mathrm{T}_{\text {reg }}$ cells, modulate Toll-like receptor 4 signalling, suppress the production of proinflammatory cytokines, and reduce the infiltration of colonic mucosa by leukocytes, thereby directly suppress the immune response and regulate colonic inflammatory processes [Van der Beek et al., 2017]. Directly under the necrosis area in all groups treated with TNBS was a zone of leukocyte infiltration (Figure 2). Moreover, under the zone of leukocyte infiltration, the CCM group had a considerably smaller area of connective tissue with edema and infiltration of eosinophil cells and fibroblasts than the $\mathrm{CC}$ group had $(\mathrm{P}<0.05)$ (Figure 1 and 2, Table 5). The infiltration of cells with the ability to produce pro-inflammatory mediators or cytokines affects the formation and differentiation of the connective tissue [Debnath et al., 2013]. Of great importance is the infiltration of eosinophil cells, which potentiates inflammatory processes such as the formation of young granulation tissue. In all animals treated with TNBS, there was an increase in new connective tissue, which was dominated by fibroblasts and numerous eosinophil cells as well as single plasmatic cells and mononuclear macrophages. In all 
TABLE 5. Effects of chicory root preparations on the histopathology of colitis induced in rats by TNBS.

\begin{tabular}{|c|c|c|c|}
\hline & \multicolumn{3}{|c|}{ Group $^{1}$} \\
\hline & $\mathrm{CC}$ & $\mathrm{CCF}$ & CCM \\
\hline Mucosal necrosis $(\mu \mathrm{m})$ & $262 \pm 7.8^{\mathrm{a}}$ & $211 \pm 19.2^{b}$ & $145 \pm 10.7^{\mathrm{c}}$ \\
\hline $\begin{array}{l}\text { Leukocyte infiltration under } \\
\text { the necrosis zone }(\mu \mathrm{m})\end{array}$ & $144 \pm 15.0$ & $131 \pm 14.7$ & $114 \pm 15.5$ \\
\hline $\begin{array}{l}\text { Connective tissue with } \\
\text { edema and infiltration } \\
\text { of eosinophils, plasmatic } \\
\text { cells and fibroblasts }(\mu \mathrm{m})\end{array}$ & $416 \pm 13.0^{\mathrm{a}}$ & - & $65.5 \pm 19.1^{\mathrm{b}}$ \\
\hline $\begin{array}{l}\text { Granulation tissue with } \\
\text { eosinophilic infiltration }(\mu \mathrm{m})\end{array}$ & $1124 \pm 34.5^{\mathrm{a}}$ & $843 \pm 57.2^{b}$ & $1096 \pm 24.3^{\mathrm{a}}$ \\
\hline $\begin{array}{l}\text { Signs of glandular } \\
\text { mucosa regeneration } \\
\text { (no. of rats out of } 8 \text { ) }\end{array}$ & 5 & 3 & 7 \\
\hline $\begin{array}{l}\text { Histopathological } \\
\text { Colitis Score (HCS) }\end{array}$ & $10 \pm 2^{a}$ & $6 \pm 2^{b}$ & $4 \pm 1^{b}$ \\
\hline
\end{tabular}

Values are expressed as the mean \pm standard error of the mean; TNBS, trinitrobenzenesulfonic acid. ${ }^{1} \mathrm{CC}$, control rats with induced colitis fed a diet with dietary cellulose; CCF, rats with induced colitis fed a diet with a dietary fructooligosaccharide preparation; CCM, rats with induced colitis fed a diet containing chicory root meal. ${ }^{\mathrm{ac}} \mathrm{C} V \mathrm{alues}$ with different superscript letters within a row are significantly different at $\mathrm{P} \leq 0.05$. The scoring method for HCS is described in Table 2.

animals treated with TNBS, the largest thickness of the new connective tissue in the colon was observed in the rats fed cellulose and chicory meal $(\mathrm{P}<0.05)(\mathrm{CC}>\mathrm{CCM}$; Table 4$)$. Furthermore, the infiltration of lymphocytic and eosinophil cells in the muscularis and under the colonic adventitia was observed in all animals. In both preparations examined, the addition of chicory meal to the diet most effectively stimulated the regeneration of the glandular mucosa in the form of small foci or the renewal of intestinal epithelial glands (Figure 2). Also the value of Histopathological Colitis Score used to evaluate histological lesions in the inflamed colon presented more favourable effect of chicory meal than of FOS $(\mathrm{CCM}<\mathrm{CCF}<\mathrm{CC}$; Table 5).

\section{CONCLUSIONS}

The present study showed that the meal from chicory roots and the commercial chicory preparation of fructooligosaccharides exerted positive changes in rats with TNBS-induced colitis. Both examined preparations significantly reduced the $\mathrm{pH}$ value of colonic digesta and favourably lowered the activity of bacterial $\beta$-glucuronidase as well as the production of putrefactive SCFAs in rats treated with TNBS. Nevertheless, only the dietary chicory root meal treatment favourably increased the SCFAs concentration and decreased the $\mathrm{pH}$ value of caecal digesta. Moreover, the morphological characteristics of the colon showed that the feeding with the diet containing chicory root meal most effectively reduced TNBS-induced colitis by reducing the level of mucosal necrosis and the field of granulation tissue with eosinophilic infiltration, as well as by increasing the signs of glandular mucosal regeneration (7/8 animals). The observed beneficial effects of chicory root meal might be related to the higher po- lymerization of inulin ( $v s$. FOS) and to the presence of biologically active compounds, e.g., phenolic compounds, which have a strong impact on intestinal microbial activity and thus indirectly alleviate colonic mucosal disturbances caused by colitis. Based on these results, the examined chicory products, especially chicory root meal, might be considered a valuable source of dietary fibre that regulates the intestinal physiological fermentative processes and thus reduces disorders associated with colitis. Further in vivo studies are needed to better understand the potential clinical relevance of chicory products in processes related to the abnormalities in the gut immune system associated with inflammatory bowel disease.

\section{REFERENCES}

1. Barcelo, A., Claustre, J., Moro, F., Chayvialle, J., Cuber, J., Plaisancie, P. (2000). Mucin secretion is modulated by luminal factors in the isolated vascularly perfused rat colon. Gut, 46(2), 218-224.

2. Cardona, M.E., Collinder, E., Stern, S., Tjellström, B., Norin, E., Midtvedt, T. (2005). Correlation between fecal iso-butyric and iso-valeric acids in different species. Microbial Ecology in Health and Disease, 17(3), 177-182.

3. Cherbut, C., Michel, C., Lecannu, G. (2003). The prebiotic characteristics of fructooligosaccharides are necessary for reduction of TNBS-induced colitis in rats. The Journal of Nutrition, 133(1), 21-27.

4. De Pascual-Teresa, S., Santos-Buelga, C., Rivas-Gonzalo, J.C. (2000). Quantitative analysis of flavan-3-ols in Spanish foodstuffs and beverages. Journal of Agricultural and Food Chemistry, 49(11), 5331-5337.

5. Debnath, T., Kim, D.H., Lim, B.O. (2013). Natural products as a source of anti-inflammatory agents associated with inflammatory bowel disease. Molecules, 18(6), 7253-7270.

6. Dell, R.D., Holleran, S., Ramakrishnan, R. (2002). Sample size determination. ILAR Journal, 43(4), 207-213.

7. Engel, M.A., Kellermann, C.A., Rau, T., Burnat, G., Hahn, E.G., Konturek, P.C. (2008). Ulcerative colitis in AKR mice is attenuated by intraperitoneally administered anandamide. Journal of Physiology Pharmacology, 59(4), 673-689.

8. Directive 2010/63/EU of the European Parliament and of the Council of 22 September 2010 on the protection of animals used for scientific purposes (2010). Official Journal of the European Union, L 276, 20.10.2010, p. 33-79.

9. Fischer, A.H., Jacobson, K.A., Rose, J., Zeller, R. (2008). Hematoxylin and eosin staining of tissue and cell sections. Cold Spring Harbor Protocols, 1;2008:pdb.prot4986. [http://cshprotocols. cshlp.org/content/2008/5/pdb.prot4986.long].

10. Fotschki, B., Juśkiewicz, J., Sojka, M., Jurgoński, A., Zduńczyk, Z. (2015). Ellagitannins and flavan-3-ols from raspberry pomace modulate caecal fermentation processes and plasma lipid parameters in rats. Molecules, 20(12), 22848-22962.

11. Fotschki, B., Milala, J., Jurgoński, A., Karlińska, E., Zduńczyk, Z., Juśkiewicz, J. (2014). Strawberry ellagitannins thwarted the positive effects of dietary fructooligosaccharides in rat cecum. Journal of Agricultural and Food Chemistry, 62(25), SI, 5871-5880.

12. Ganaie, M.A., Lateef, A., Gupta, U.S. (2014). Enzymatic trends of fructooligosaccharides production by microorganisms. Applied Biochemistry and Biotechnology, 172 (4), 2143-2159. 
13. Gibson, G.R., Beatty, E.R., Wang, X., Cummings, J.H. (1995). Selective stimulation of the bifidobacteria in the human colon by oligofructose and inulin. Gastroenterology, 108(4), 975-982.

14. Gonçalves, C.C.M., Hernandes, L., Bersani-Amado, C.A., Franco, S.L., Silva, J.F.D.S., Natali, M.R.M. (2013). Use of propolis hydroalcoholic extract to treat colitis experimentally induced in rats by 2,4,6-trinitrobenzenesulfonic acid. Evidence-Based Complementary and Alternative Medicine, 2013, art. no. 853976.

15. Hamer, H.M., Jonkers, D., Venema, K., Vanhoutvin, S., Troost, F.J., Brummer, R.J. (2008). Review article: The role of butyrate on colonic function. Alimentary Pharmacology \& Therapeutics, 27(2), 104-119.

16. Hofirek, B., Haas, D. (2001). Comparative studies of ruminal fluid collected by oral tube or by puncture of the caudorental ruminal sac. Acta Veterinaria Brno, 70(1), 27-33.

17. Jurgoński, A., Fotschki, B., Juśkiewicz, J. (2015). Disparate metabolic effects of blackcurrant seed oil in rats fed a basal and obesogenic diet. European Journal of Nutrition, 54(6), 991-999.

18. Jurgoński, A., Milala, J., Juśkiewicz, J., Zduńczyk, Z., Król, B. (2011). Composition of chicory root, peel, seed and leaf ethanol extracts and biological properties of their non-inulin fractions. Food Technology and Biotechnology, 49(1), 40-47.

19. Juśkiewicz, J., Milala, J., Jurgoński, A., Król, B., Zduńczyk, Z. (2011a). Consumption of polyphenol concentrate with dietary fructo-oligosaccharides enhance cecal metabolism of quercetin glycosides in rats. Nutrition, 27(3), 351-357.

20. Juśkiewicz, J., Zduńczyk, Z., Żary-Sikorska, E., Król, B., Milala, J., Jurgoński, A. (2011b). Effect of the dietary polyphenolic fraction of chicory root, peel, seed and leaf extracts on caecal fermentation and blood parameters in rats fed diets containing prebiotic fructans. The British Journal of Nutrition, 105(5), 710-720.

21. Klewicka, E., Zduńczyk, Z., Juśkiewicz, J. (2009). Effect of lactobacillus fermented beetroot juice on composition and activity of cecal microflora in rats. European Food Research and Technology, 229(1), 153-157.

22. Kosmala, M., Jurgoński, A., Juśkiewicz, J., Karlińska, E., Macierzyński, J., Rój, E., Zduńczyk, Z. (2017). Chemical composition of blackberry press cake, polyphenolic extract, and defatted seeds, and their effects on cecal fermentation, bacterial metabolites, and blood lipid profile in rats. Journal of Agricultural and Food Chemistry, 65(27), 5470-5479.

23. Kosmala, M., Zduńczyk, Z., Juśkiewicz, J., Jurgoński, A., Karlińska, E., Macierzyński, J., Jańczak, R., Rój, E. (2015). Chemical composition of defatted strawberry and raspberry seeds and the effect of these dietary ingredients on polyphenol metabolites, intestinal function, and selected serum parameters in rats. Journal of Agricultural and Food Chemistry, 63(11), 2989-2996.

24. Kosmala, M., Zduńczyk, Z., Kołodziejczyk, K., Klimczak, E., Juśkiewicz, J., Zduńczyk, P. (2014). Chemical composition of polyphenols extracted from strawberry pomace and their effect on physiological properties of diets supplemented with different types of dietary fibre in rats. European Journal of Nutrition, 53(2), 521-532.

25. Lahouar, L., Pochart, P., Salem, H.B., El Felah, M., Mokni, M., Magne, F., Mangin, I., Suau, A., Pereira, E., Hammami, M., Achour, L. (2012). Effect of dietary fibre of barley variety "Rihane" on azoxymethane-induced aberrant crypt foci development and on colonic microbiota diversity in rats. The British Journal of Nutrition, 108(11), 2034-2042.
26. Lara-Villoslada, F., Debras, E., Nieto, A., Concha, A., Gálvez, J., López-Huertas, E., Boza, J., Obled, C., Xaus, J. (2006). Oligosaccharides isolated from goat milk reduce intestinal inflammation in a rat model of dextran sodium sulfate-induced colitis. Clinical Nutrition, 25(3), 477-488.

27. Liu, X., Wang, J. (2011). Anti-inflammatory effects of iridoid glycosides fraction of Folium syringae leaves on TNBS-induced colitis in rats. Journal of Ethnopharmacology, 133(2), 780-787.

28. Louis, P., Flint, H.J. (2017). Formation of propionate and butyrate by the human colonic microbiota. Environmental Microbiology, 19(1), 29-41.

29. Morris, G.P., Beck, P.L., Herridge, M.S., Depew, W.T., Szewczuk, M.R., Wallace, J.L. (1989). Hapten-induced model of chronic inflammation and ulceration in the rat colon. Gastroenterology, 96(3),795-803.

30. Motavallian-Naeini, A., Andalib, S., Rabbani, M., Mahzouni, P., Afsharipour, M., Minaiyan, M. (2012). Validation and optimization of experimental colitis induction in rats using 2, 4, 6-trinitrobenzene sulfonic acid. Research in Pharmaceutical Sciences, 7(3), 159-169.

31. Ramirez-Farias, C., Slezak, K., Fuller, Z., Duncan, A., Holtrop, G., Louis, P. (2009). Effect of inulin on the human gut microbiota: stimulation of Bifidobacterium adolescentis and Faecalibacterium prausnitzii. The British Journal of Nutrition, 101(4), 541-550.

32. Roberton, A.M., Stanley, R.A., Lee, S.P., Lindop, R., Thomsen, L., Jones, C.T. (1982). Biliary control of $\beta$-glucuronidase activity in the luminal contents of the rat ileum, cecum, and rectum. Cancer Research, 42(12), 5165-5166.

33. Rodríguez-Cabezas, M.E., Gálvez, J., Lorente, M.D., Concha, A., Camuesco, D., Azzouz, S., Osuna, A., Redondo, L., Zarzuelo, A. (2002). Dietary fiber down-regulates colonic tumor necrosis factor $\alpha$ and nitric oxide production in trinitrobenzenesulfonic acid-induced colitic rats. The Journal of Nutrition, 132(11), 3263-3271.

34. Shimotoyodome, A., Meguro, S., Hase, T., Tokimitsu, I., Sakata, T. (2000). Short chain fatty acids but not lactate or succinate stimulate mucus release in the rat colon. Comparative Biochemistry and Physiology. Part A, Molecular \& Integrative Physiology, 125(4), 525-531.

35. Singh, R.S., Singh, R.P., Kennedy, J.F. (2016). Recent insights in enzymatic synthesis of fructooligosaccharides from inulin. International Journal of Biological Macromolecules, 85, 565-572.

36. Sturm, A., Dignass, A.U. (2008). Epithelial restitution and wound healing in inflammatory bowel disease. World Journal of Gastroenterology, 14(3), 348-353.

37. Topping, D.L., Clifton, P.M. (2001). Short-chain fatty acids and human colonic function: roles of resistant starch and nonstarch polysaccharides. Physiological Reviews, 81 (3), 1031-1064.

38. van der Beek, C.M., Dejong, C.H.C., Troost, F.J., Masclee, A.A.M., Lenaerts, K. (2017). Role of short-chain fatty acids in colonic inflammation, carcinogenesis, and mucosal protection and healing. Nutrition Reviews, 75(4), 286-305.

39. Vinolo, M.A.R., Rodrigues, H.G., Nachbar, R.T., Curi, R. (2011). Regulation of inflammation by short chain fatty acids. Nutrients, 3(10), 858-876.

40. Wang, L., Liu, H.M., Xie, A.J., Zhu, C.Y., Qin, G.Y. (2018). Dietary fiber extraction from defatted corn hull by hot-compressed water. Polish Journal of Food and Nutrition Sciences, 68(2), 133-140. 
41. Witaicenis, A., Fruet, A.C., Salem, L., Di Stasi, L.C. (2010). Dietary polydextrose prevents inflammatory bowel disease in trinitrobenzenesulfonic acid model of rat colitis. Journal of Medicinal Food, 13(6), 1391-1396.

42. Yajima, T., Inoue, R., Matsumoto, M., Yajima, M. (2011). Nonneuronal release of ACh plays a key role in secretory response to luminal propionate in rat colon. The Journal of Physiology, 589(4), 953-962.

43. Yue-Meng, W., You-Qing, Z., Bing, X., Jun, L. (2011). Treating TNBS-induced colitis in rats with probiotics. Turkish Journal of Gastroenterology, 22(5), 486-493.

44. Żary-Sikorska, E., Juśkiewicz, J. (2008). Effect of fructans with different degrees of polymerization on bacterial enzymes activity, lipid profile and antioxidant status in rats. Polish Journal of Food and Nutrition Sciences, 58(2), 269-272.

45. Żary-Sikorska, E., Juśkiewicz, J., Jundziłł, A., Rybka, J. (2016). Effects of diets varying in the type of dietary fibre and its combination with polyphenols on gut function, microbial activity and antioxidant status in rats. Journal of Animal and Feed Sciences, 25(3), 250-258.

46. Zhang, Y-Z., Li Y-Y. (2014). Inflammatory bowel disease: pathogenesis. World Journal of Gastroenterology, 20(1), 91-99.

47. Zhong, J., Luo, B.Y., Xiang, M.J., Liu, H.W., Zhai, Z.K., Wang, T.S., Craig, S.A.S. (2000). Studies on the effects of polydextrose intake on physiologic functions in Chinese people. The American Journal of Clinical Nutrition, 72(6), 1503-1509.

48. Zorrilla, P., Rodriguez-Nogales, A., Algieri, F., Garrido-Mesa, N., Olivares, M., Rondón, D., Zarzuelo, A., Utrilla, M.P., Galvez, J., Rodriguez-Cabezas, M.E. (2014). Intestinal anti-inflammatory activity of the polyphenolic-enriched extract Amanda ${ }^{\circledR}$ in the trinitrobenzenesulphonic acid model of rat colitis. Journal of Functional Foods, 11, 449-459.

Submitted: 16 November 2018. Revised: 23 January and 8 February 2019. Accepted: 21 February 2019. Published on-line: 26 March 2019. 